\title{
Corporate Payout Policy in Turkey: Does Market Power Affect the Dividend Payout?
}

\author{
Çiğdem VURAL YAVAŞ ${ }^{1}$
}

https://orcid.org/0000-0002-3440-4762

\begin{abstract}
The primary purpose of this paper is to explore the relationship between corporate dividend-payout policy and the competition in the product market for the listed companies in Turkey using a panel data of non-financial firms over the period 2007 to 2015. Turkey is an emerging market classified as a French-civil-law country with weak protection of investors. Using Turkish firms, we analyze the effect of competition on dividend-payout policy, under weak investor protection. Our results indicate that competition measured by the Herfindahl-Hirschman Index and 5 -firm concentration ratio significantly affects dividend payout. Our findings show that competition in the industry negatively influences the dividend payout. The results demonstrate that in highly competitive industries, Turkish firms pay lower dividends than the firms in concentrated industries to remain competitive in the market. Moreover, large profitable firms with lower investment opportunities and lower tangible assets distribute higher dividends to their shareholders in Turkey.

Keywords: Dividend yield, payout policy, dividend payout, product market competition, market power, emerging market, Turkey.
\end{abstract}

\section{Introduction}

Recent studies on corporate governance have shown that competition in the market has a disciplinary force on the management of firms (Allen \& Gale, 2000; Giroud \& Mueller, 2010, 2011; Ammann, Osech \& Schmid, 2011; Kim \& Lu, 2011). Similar to the takeover market, product-market competition is also accepted as an external control mechanism on management. Competition decreases agency costs by decreasing managerial slack (Giroud \& Mueller, 2010). The disciplinary role of competition on management makes the competition an effective factor in firm decisions.

Having a large amount of free cash flow makes the firm a target in the takeover market (Jensen, 1986). Similarly, product market competition affects the free cash flow level. There are two different views on this issue. According to the first view, in a highly competitive environment, the management of a firm needs to hold free-cash flow to make necessary moves against its competitors. According to the other opinion, in highly competitive industries, both the risk and the cost of overinvestment increase; therefore, instead of investing in high risk projects, management distributes excess cash to shareholders.

This study aims to examine how competition in the product market affects the corporate dividend-payout policy. The hypothesis that the competition affects the corporate payout policy will be tested with three different dividend-payout proxies and with six different regressions. The details of the empirical analysis will be given in the following sections. This paper contributes to the literature along two dimensions. First, the product-market competition will be used as a dividend-payout determinant. Competition is an external disciplinary mechanism for corporations, and its effect on corporate payout decisions will be shown in this study. Second, foreign ownership will also be added as a dividend-payout determinant as an information-asymmetry proxy. As a result of findin$\mathrm{gs}$, we aim to provide a guide for both the academic and the corporate world by measuring the impact of competition on the corporate payout policy.

The paper is organized as follows: While the literature on the effect of competition on corporate decisions will be analyzed in the next section, following section

${ }^{1}$ Kadir Has Üniversitesi, İşletme Fakültesi, Uluslararası Ticaret ve Finans Bölümü, İstanbul, cigdem.yavas@khas.edu.tr 
will be the methodology including data, the definition of variables, and method specification. Empirical results will be exhibited in the fourth section, and the paper will be finalized with the conclusion section.

\section{Literature}

Many recent studies have been conducted to analyze the relationship between corporate governance and competition in the product market. Allen and Gale (2000) accept product market competition as a corporate governance mechanism. They state that the effect of the competition is more powerful than both the internal monitoring impact of institutional investors and external corporate control. Moreover, the competition itself serves as a monitoring mechanism and reduces agency conflicts (Allen \& Gale, 2000). In other words, in intensely competitive markets, managerial interest aligns with shareholder interest (He, 2012; Guadalupe \& Perez-Gonzales, 2010; Schmidt, 1997). Thus, omitting dividends is less likely, and even the current dividends are more likely to be increased. In fact, in highly competitive industries, CEO turnover is higher than in concentrated industries (Fee \& Hadlock, 2000; Raith, 2003). Such pressure of competition on management is a disciplinary mechanism that motivates managers to act in favor of shareholders by trying to maximize the firm value. Moreover, a highly competitive environment discourages managers to invest in high-risk projects because the performance of a manager can be easily compared with other management teams of competitors in the industry (Grullon \& Michaely, 2007).

Giroud and Muller (2011) demonstrate that corporate governance is unnecessary in highly competitive industries. However, in low competition industries, firms do need good corporate governance. These findings support the hypothesis of substitution of competition with corporate governance. In intensely competitive industries, management is forced to maximize firm value by the competition in the market, which makes good governance unnecessary. On the other hand, in low competition industries, good governance improves firm value (Giroud \& Muller, 2011). Supporting Giroud and Mueller's findings, Ammann, Osech, and Schmid (2011) conducted their studies with 14 European countries and found that firm value is appreciated only in weakly competitive industries. Another example supporting the substitution hypothesis is conducted on Korean firms by Byun, Lee, and Park (2012), indicating that the adverse effect of governance on corporate payout decreases when the market competition is weak, and this negative effect even disappears when the competition is high. In a study conducted by Kim and Lu (2011), by labeling managerial ownership as an internal corporate monitoring mechanism, the substitution hypothesis of external governance mechanism by product market competition is supported.

Even though there is a consensus on the interaction of internal corporate governance mechanisms and product market competition, there is no thorough understanding through which channel competition affects a firm's decision. Based on the literature listed above, it is a fact that product market competition affects agency conflicts. Agency considerations have an important role in corporate payout decisions (DeAngelo, DeAngelo \& Stulz, 2006; Lie, 2000). La Porta, Lopez-de-Silanes and Shleifer (2000) state two dividend models from the perspective of agency theory: the substitute agency model and the outcome agency model. According to the substitute agency model, firms pay dividends to establish a reputation in the market to raise capital in the future. On the other hand, according to the outcome model managers pay dividend with the force of effective minority shareholders. These two dividend models imply different dividend payout policy with the strength of corporate governance. Substitution agency model predicts a decrease in dividend payments when corporate governance increases. Contrary, the outcome model implies an increase in dividend payments with the strength of corporate governance.

Moreover, Grullon and Michaely (2007) claim that corporate payout policy is affected by the interaction between managerial incentives and market competition. Grullon and Michaely's (2007) study supports the outcome model in the U.S. which is a common law county having strong minority shareholder protection. According to the outcome model, firm liquidation risk is increased with an increase in competition in the market which as a result, the overinvestment risk is reduced, which in turn, becomes an incentive for the dividend payout.

On the other hand, Kao and Chen (2013) conclude that the outcome model is only applicable when firms are in intensely competitive industries. However, in a low competition environment, the substitution model, in which dividend payout is utilized as a signaling device under information asymmetry, is supported. According to the substitution model, firms located in weak governance zones pay more dividends to mitigate their agency problems and lower their cost of capital (Byun, Lee \& Park, 2014). Kao and Chen (2013)'s fin- 
dings demonstrate a non-linear relationship between dividend payment and competition in a country where investors are weakly protected. Moreover, supporting Kao and Chen's results, Byun, Lee and Park (2014) conclude that the negative effect of corporate governance on the corporate payout is stronger in concentrated industries whereas this negative effect decreases or even disappears in intensely competitive industries. In a study conducted for publicly listed companies in Japan, $\mathrm{He}$ (2012) analyzes dividend policy of companies to understand whether product market competition reduces agency conflicts. His results indicate that more dividends are paid by firms operating in highly competitive industries. In fact, firms increase dividend payout instead of omitting when competition in the market is high.

Based on the literature review conducted above, it can be stated that product market competition has a significant role in corporate dividend payout decisions. Consequently, the purpose of this study will be to explore the relationship between dividend payout policy and competition for firms operating in a French civil law country, Turkey, where shareholder protection is weak

\section{Methodology}

\subsection{Data}

The initial sample for empirical analysis consists of non-financial-listed firms between 2007 and 2015. The primary dataset includes 331 non-financial-listed firms between 2008 and 2015 since a one-year lag is necessary for some of the variable calculations. Financial institutions such as banks, insurance companies, investment companies, brokerage firms, and real estate investment trusts are excluded from the sample due to the difference in their accounting practice concerning that of non-financial firms. The sample includes manufacturing, construction, public work, wholesale and retail trade, hotels and restaurants, electric, gas and water, transportation, communication and data storage, and technology industries.

Competition in the market is quantified by the Herfindahl-Hirschman Index (HHI). It is the sum of squares of the market shares of the firms in an industry. By construction, $\mathrm{HHI}$ values range from 0 to 1 . As $\mathrm{HHI}$ approaches to 0 , it indicates high competition, whereas as it is close to 1, the industry is deemed to be "concentrated." In this study, the three-digit International Standards Industrial Classification (ISIC) is used to classify industries.
The data is collected from three main sources. For the secondary data of financial statements, the FINNET database is utilized. For ownership data, the source is the Turkish Central Registry Agency (e-MKK) Information Portal. The top 1000 Industrial Enterprises List of the Istanbul Chamber of Industry is used to quantify the product market competition for industries whose ISIC code is between 100 and 400 . For the other industries, all the listed firms in BIST are used to quantify industry product market competition.

\subsection{Variables}

In this paper, we use three variables to estimate the dividend payout policy of a firm. The three dependent variables are:

a) The dividend yield

b) The ratio of the total annual dividend payout to market value of the firm.

c) The ratio of the total annual dividend payout to sales of the firm.

The main independent variable in this study is the competition in the industry that the firm operates. Herfindahl-Hirschman Index is used to estimate the competition. It is calculated as the sum of squares of the market share of each firm in an industry, each of which is labeled with a three-digit ISIC code. $\mathrm{HHI}$ can be expressed as,

$$
H H I_{j, t}=\sum s_{i, j, t}^{2}
$$

where $s_{i j t}$ is the market share of firm i in industry jor year $\mathrm{t}$. $\mathrm{HHI}$ is between 0 and 1. Market share of a firm is defined as the ratio of sales of the firm to the total sales of the industry that the firm belongs. We include all the firms having ISIC code between 100 and 400 in the top 1000 Industrial Enterprises List of the Istanbul Chamber of Industry which have positive sales value. For the other industries, we use all the non-financial listed companies in BIST. We exclude firms having either missing sales information or negative sales since negative sales cause miscalculation of $\mathrm{HHI}$ due to the square of market share term in the formulation.

In addition to $\mathrm{HHI}$, we employ a concentration ratio as an alternative competition measure. The calculation of the concentration ratio also depends on the market share of firms. It is the sum of the market share percentage held by the largest specified number of firms in an industry. Most commonly used concentration measures 
are 3-firm, 4-firm or 5-firm concentration ratios. In this study, we use 5-firm concentration ratio.
Table 1 displays the brief descriptions of the variables used in the empirical analysis.

Table 1: Variables

\begin{tabular}{|c|c|c|}
\hline Variable & Definition & Source \\
\hline Dividend yield & Annual dividend payments / Initial stock price & FINNET \\
\hline Dividend/MV & Annual dividend payments / Market Value & FINNET \\
\hline Dividend/Sales & Annual dividend payments / Net Sales & FINNET \\
\hline $\mathrm{HHI}$ & $\begin{array}{l}\text { Herfindahl-Hirschman Index: The sum of squares of the } \\
\text { market share of each firm in an industry for each year. }\end{array}$ & $\begin{array}{l}\text { The top } 1000 \text { Industrial Enterprises List of } \\
\text { the Istanbul Chamber of Industry, FINNET }\end{array}$ \\
\hline 5-firm concentration & $\begin{array}{l}\text { 5-firm concentration ratio is calculated as the sum of the } \\
\text { market share percentage held by the largest five firms in } \\
\text { an industry for each year }\end{array}$ & $\begin{array}{l}\text { The top } 1000 \text { Industrial Enterprises List of } \\
\text { the Istanbul Chamber of Industry, FINNET }\end{array}$ \\
\hline High Comp. & $\begin{array}{l}\text { 1, if the industry competition is smaller than the median } \\
\text { of HHI values } \\
0 \text {, otherwise }\end{array}$ & $\begin{array}{l}\text { The top } 1000 \text { Industrial Enterprises List of } \\
\text { the Istanbul Chamber of Industry, FINNET }\end{array}$ \\
\hline Low Comp. & $\begin{array}{l}\text { 1, if the industry competition is greater than the median } \\
\text { of } \mathrm{HHI} \text { values } \\
0, \text { otherwise }\end{array}$ & $\begin{array}{l}\text { The top } 1000 \text { Industrial Enterprises List of } \\
\text { the Istanbul Chamber of Industry, FINNET }\end{array}$ \\
\hline Size & In(market capitalization) & FINNET \\
\hline MV/BV & (MV(Equity) + BV(liabilities)) / BV(Total Assets) & FINNET \\
\hline Sales Growth & $\left(\right.$ Sales $_{t}-$ Sales $\left._{t-1}\right) /$ Sales $_{t-1}$ & FINNET \\
\hline Leverage & Total Debt / Total Asset & FINNET \\
\hline Profitability & Return on assets (ROA) & FINNET \\
\hline Asset Str & Tangibility = Plant, property, and equipment $/$ TA & FINNET \\
\hline Foreign Own. & Foreign ownership percentage & $\begin{array}{l}\text { The Turkish Central Registry Agency } \\
\text { (e-MKK) Information Portal }\end{array}$ \\
\hline
\end{tabular}

Note: The financial variables are from FINNET database. The period of the financial data is between 2007 to 2015 . For the calculation of some variables, one-year lagged value is necessary. Therefore, in the analyses the sample period is between 2008 to 2015.

Highly competitive industries have HHI values close to zero whereas industries having weak competition have $\mathrm{HHI}$ values close to one. Therefore, a positive (negative) coefficient of $\mathrm{HHI}$ in the empirical analysis indicates a negative (positive) impact of competition. Similarly, higher $n$-firm concentration measure means that the $\mathrm{n}$ largest firms in the industry hold a higher portion of the market share which indicates that the $n$ largest firms have the market power and competition level in the industry is low. On the other hand, when the $n$-firm concentration ratio is low, this means that the $\mathrm{n}$ largest firms have a low portion of market share indicating that the industry is highly competitive.

In line with dividend policy literature, the following variables are used as control variables:

- Size: The natural logarithm of the market capitalization of a firm. In line with the related literature, higher dividend payout is expected for large firms (Jensen, Solberg \& Zorn, 1992; Redding, 1997; Fama \& French, 2001; Denis \& Osobov, 2008). 
- Leverage: The ratio of total debt to total assets of a firm. The use of leverage can be a complement or a substitute for dividend which affects the relationship between leverage and dividend payout (Grullon \& Michaely, 2007). Highly levered firms are expected to pay less dividend as they have to meet their future payments.

- Investment Opportunities: Market-to-book ratio and sales growth are the two proxies that we use to quantify investment opportunities of firms. For sales growth calculation, we use a one-year lag. Therefore, our time index starts from 2008, not 2007. Lower dividend payment is expected for firms having high revenue growth as these firms need financing for their valuable projects and it will be costly to use external financing (Higgins, 1972; Rozeff, 1982).

The ratio of market value of assets to book value of assets is used to estimate market-to-book ratio. The market value of assets is estimated by the sum of the market value of equity and the book value of liabilities. Market-to-book ratio is the most commonly used investment opportunity proxy in the finance literature. Firms having higher market-to-book ratio are accepted as firms having higher investment opportunities. These kinds of firms need more cash for their future investments. Hence, instead of paying dividends to their shareholders, they keep cash for their investments. Therefore, it is expected to have a negative relationship between the market-to-book ratio and dividend payments.

- Profitability: The proxy for profitability is the return on assets (ROA). It is estimated by the net income to total assets. The dividend payment is likely for the firms having higher profit (Banerjee, Gatchev \& Spindt, 2002; Denis \& Osobov, 2008). Moreover, the dividend payment of firms depends on the current year's earnings and the previous year's dividend payment (Lintner, 1956; Baker, Farrelly \& Edelman, 1985). Hence, it is expected to have a positive impact of profitability on the dividend payments of a company.

- Asset Structure: The ratio of plant, property, and equipment to total assets is the proxy used to estimate the asset structure of a firm. The tangibility of a firm represents the long-term assets in the firm's asset structure. Firms having higher level of tangible assets are expected to have less difficulty to maintain the dividend payment. Thus, it is expected to have a positive relationship between tangibility and dividend payout.

- Foreign Ownership: In an emerging market, foreign ownership is an important factor in corporate policy. The foreign ownership percentage is used to control the effect of foreign investors. In the developing economies, most of the foreign owners are institutional investors who serve the monitoring function and reduce the information asymmetry. In a study conducted for the Korean stock market by Jeon, Lee, and Moffett (2011), a positive impact of foreign investors on the dividend payout is reported.

The variables of dividend payout proxies (dividend yield, the ratio of dividend payments to total sales and the ratio of dividend payments to market value of a firm), competition ( $\mathrm{HHI}$ and 5 -firm concentration), size, market-to-book ratio, leverage, profitability, sales growth, tangibility, and asset structure are winsorized at levels $1 \%$ and $99 \%$, to mitigate the effect of outliers in the analysis.

\subsection{Methodology}

Before starting the empirical analysis, it is necessary to test the possible existence of multicollinearity between the independent variables. The preliminary analysis for multicollinearity is correlation analysis. According to the Pearson correlation results given in Table 1, the maximum correlation, which is $63.5 \%$, is between the variables of size and foreign ownership. Tolerance and variance inflation factor (VIF) measures should also be checked to ensure the lack of multicollinearity. Tolerance should be high, and VIF should be low enough in order not to have a multicollinearity problem. For tolerance, the threshold value is 0.10 , and for VIF, the threshold value is 10 (Hair, Black, Babin \& Anderson, 2010). According to the unreported VIF and tolerance results, all of the tolerance values for the independent variables are higher than the threshold value 0.10 . Similarly, all of the VIF values are smaller than 10 . In fact, the tolerance between size and foreign ownership is 0.864 whereas the VIF is 1.157 . Therefore, the nonexistence of multicollinearity assumption is met. 
Table 2: Correlation Matrix

\begin{tabular}{|c|c|c|c|c|c|c|c|c|c|}
\hline Variables & $\mathrm{HHI}$ & 5-firm & Size & MV/BV & Leverage & Profit & SalesGrwth & AssetStr. & ForOwn \\
\hline $\mathrm{HHI}$ & 1 & & & & & & & & \\
\hline 5-firm con. & $0.998 * * *$ & 1 & & & & & & & \\
\hline Size & 0.013 & 0.012 & 1 & & & & & & \\
\hline MV/BV & -0.027 & -0.029 & $0.237^{* * *}$ & 1 & & & & & \\
\hline Leverage & $0.066^{* * *}$ & $0.067^{* * *}$ & $0.097^{* *}$ & $-0.262^{* *}$ & 1 & & & & \\
\hline Profitability & 0.017 & 0.014 & $0.222^{* * *}$ & $0.085^{* *}$ & $-0.263^{* * *}$ & 1 & & & \\
\hline Sales Grwth & $0.042^{* *}$ & $0.047^{* *}$ & $0.042^{* *}$ & 0.015 & $-0.074^{* * *}$ & $0.159 * * *$ & 1 & & \\
\hline Asset Str. & $-0.223^{* * *}$ & $-0.225^{* * *}$ & $0.091^{* * *}$ & 0.024 & -0.007 & $-0.101^{* * *}$ & -0.007 & 1 & \\
\hline ForeignOwn. & $0.107^{* * *}$ & $0.103^{* * *}$ & $0.635^{* * *}$ & $0.194^{* * *}$ & $-0.112^{* * *}$ & $0.246^{* * *}$ & 0.026 & -0.014 & 1 \\
\hline
\end{tabular}

${ }^{* * *} p=0.01 \%$, ${ }^{* *} p=0.5,{ }^{*} p=0.1$

The preliminary test for the cross-sectional dependence in the panel data with the null hypothesis that errors are weakly cross-sectional dependent is rejected. The other preliminary test for panel data analysis is slope homogeneity which requires large panel data. The panel data in this study includes 8 years and 331 cross-sections which is not enough to perform slope homogeneity test.

The empirical analysis includes six different regressions with a panel data of 325 firms and eight years. In the regressions, three different dependent variables are utilized: dividend yield, the ratio of dividend to market value, and the ratio of dividend payment to sales. In the first three regressions, Herfindahl-Hirschman Index is used as the product market competition. For the other three regressions, 5 -firm concentration measure is used as the competition measure.

We employ fixed effects panel data estimation since the Hausman specification test with the null hypothesis that the preferred model is random effects is rejected for all the model specifications in this study. To control for the year effects we use time fixed effects which capture the influence of aggregate trends. Also, to deal with the omitted variable bias, we include firm fixed effects.

The empirical model is expressed as,

Dividend Payout

$$
\begin{aligned}
& =\beta_{0}+\beta_{1} \text { Competition }_{i t}+\beta_{2} \text { Size }_{i t}+\beta_{3} M V / B V_{i t}+\beta_{4} \text { Leverage }_{i t} \\
& +\beta_{5} \text { Profitability }_{i t}+\beta_{6} \text { SalesGrowth }_{i t}+\beta_{7} \text { Asset Structure }_{i t} \\
& +\beta_{8} \text { Foreign Ownership }+\theta_{t}+\vartheta_{i}+\varepsilon_{i t}
\end{aligned}
$$

where the subscripts $\mathrm{i}$ is for firms, and $\mathrm{t}$ is for years. $\theta_{t}$ represents the time fixed effect and $\vartheta_{i}$ represents the firm fixed effect. Competition ${ }_{i t}$ can be Herfindahl-Hirschman Index or 5-firm concentration ratio.

\section{Results}

\subsection{Descriptive Statistics}

Table 3 reports the descriptive statistics for the sample. The average dividend yield is 0.0196 , whereas the average dividend to sales is 0.0206 . The median of the $\mathrm{HHI}$ is 0.1536 whereas the median of 5 -firm concentration ratio is 0.1436 . The average sales growth is 0.1238 , and some firms do have negative revenue growth. Similarly, some firms in the sample have negative profitability. 
Table 3: Descriptive Statistics

\begin{tabular}{|c|c|c|c|c|c|c|}
\hline Variables & $\mathrm{N}$ & Mean & Median & Std. Dev. & Min & Max \\
\hline Dividend Yield & 2,254 & 0.0196 & 0 & 0.0403 & 0 & 0.2042 \\
\hline Dividend/Sales & 2,451 & 0.0206 & 0 & 0.0527 & 0 & 0.3162 \\
\hline Dividend/Market Value & 2,529 & 0.0122 & 0 & 0.0282 & 0 & 0.1624 \\
\hline $\mathrm{HHI}$ & 3,021 & 0.2392 & 0.1536 & 0.2435 & 0.0122 & 1 \\
\hline 5-firm concentration & 3,022 & 0.2331 & 0.1436 & 0.2495 & 0.0049 & 1 \\
\hline Size & 2,834 & 19.2483 & 19.2151 & 2.0138 & 14.6271 & 24.1788 \\
\hline MV/BV & 2,776 & 1.5262 & 1.0986 & 1.7153 & -1.3317 & 9.4930 \\
\hline Leverage & 2,507 & 1.5604 & 0.7796 & 2.3477 & 0.0077 & 14.5103 \\
\hline Profitability & 2,773 & 0.0187 & 0.0236 & 0.1028 & -0.3733 & 0.2637 \\
\hline Sales Growth & 2,369 & 0.1238 & 0.0929 & 0.3875 & -0.9186 & 1.8638 \\
\hline Asset Structure & 2,834 & 0.3002 & 0.2853 & 0.2175 & 0 & 0.8736 \\
\hline Foreign Ownership & 2,422 & 0.2092 & 0.0488 & 0.2863 & 0 & 0.9984 \\
\hline
\end{tabular}

\subsection{Empirical Results}

The effect of product market competition on the dividend payout of the firm is analyzed in six different panel data regressions. Table 4 reports the results of the empirical analysis. In the first three regressions, the Herfindahl-Hirschman Index is the proxy for product market competition whereas for the rest of the regressions the 5 -firm concentration ratio is used.

Table 4: Empirical Results for $\mathrm{HHI}$ and 5 -firm concentration ratio

\begin{tabular}{|c|c|c|c|c|c|c|c|}
\hline Variable & Expected & Div. Yield & Div/MV & Div/Sales & Div. Yield & Div/MV & Div/Sales \\
\hline $\mathrm{HHI}$ & + & $0.0364^{* *}$ & $0.0193^{*}$ & $0.0512^{* * *}$ & & & \\
\hline 5-firm con. & + & & & & $0.0453^{* *}$ & $0.0223^{*}$ & $0.0575^{* * *}$ \\
\hline Size & + & $0.0077^{* * *}$ & $0.0053^{* * *}$ & $0.0086^{* * *}$ & $0.0079^{* * *}$ & $0.0053^{* * *}$ & $0.0087^{* * *}$ \\
\hline MV/BV & - & $-0.0019^{* *}$ & -0.0006 & 0.0007 & $-0.0019^{* *}$ & -0.0006 & 0.0007 \\
\hline Leverage & - & -0.0008 & -0.0003 & -0.0004 & -0.0008 & -0.0003 & -0.0004 \\
\hline Profitability & + & $0.0788^{* * *}$ & $0.0462^{* * *}$ & $0.0818^{* * *}$ & $0.0787^{* * *}$ & $0.0462^{* * *}$ & $0.0818^{* * *}$ \\
\hline Sales Grwth & - & 0.0013 & 0.0000 & 0.0041 & 0.0013 & 0.0000 & 0.0041 \\
\hline Asset Str. & + & $-0.0200^{* *}$ & $-0.0115^{*}$ & $-0.0238^{* *}$ & $-0.0197^{* *}$ & $-0.0114^{*}$ & $-0.0236^{* *}$ \\
\hline Foreign Own & + & $-0.0158^{* *}$ & $-0.0084^{*}$ & -0.0112 & $-0.0155^{* *}$ & $-0.0083^{*}$ & -0.0109 \\
\hline $\mathrm{R}^{2}$ & & 0.5766 & 0.6027 & 0.6676 & 0.5771 & 0.6029 & 0.6678 \\
\hline Adj. $R^{2}$ & & 0.4848 & 0.5206 & 0.5989 & 0.4855 & 0.5209 & 0.5992 \\
\hline $\mathrm{N}$ & & 1,898 & 1,980 & 1,980 & 1,899 & 1,981 & 1,981 \\
\hline
\end{tabular}

Note: We use year and firm fixed effects for all the regressions. ${ }^{* *} p=0.01 \%$, ${ }^{* *} p=0.5,{ }^{*} p=0.1$ 
In the first three regressions, $\mathrm{HHI}$ is positively significant at the $5 \%, \% 10$ or $\% 1$ level. That is, product-market competition negatively affects the dividend payout policy of the firm since the smaller the $\mathrm{HHI}$, the more intensely competitive the industry becomes. The results of the regressions with 5-firm concentration ratio support this finding as well. 5 -firm concentration ratio positively influences the dividend payout. The significance level for the regressions is $5 \%, 10 \%$ or $1 \%$. That is to say, the firms pay less dividend when they are in a highly competitive industry.

In line with the related literature, size is positively significant at $1 \%$ level in all regressions. Large firms pay more dividend than small ones. Investment opportunities, proxied by market-to-book ratio, is negatively significant only for the regression with dividend yield dependent variable. The market-to-book ratio has a negative sign for the other regressions as well. But, in the other regressions, it is not significant. Firms having higher investment opportunities are expected to use excess cash to invest in valuable projects rather than paying dividends to their shareholders. Thus, it is expected to have a negative impact of market-to-book ratio on the dividend payout policy. On the other hand, the other investment opportunity proxy used in the analyses, sales growth, is not significant in the regressions.

Grullon and Michaely (2007) claim that the effect of leverage on dividend payout depends on whether a firm uses leverage as a substitute or a complement for the dividend payout. So, the impact of leverage on dividend payout can be positive or negative. But, in this study, we argue that in developing countries highly levered firms have problems to meet their payments. Therefore, it will be difficult to maintain dividend payment for a highly levered firm. The coefficient of leverage is negative in the empirical analyses, but they are not significant.

The other control variable, profitability, is positively significant in all regressions as expected. Highly profitable firms will not have difficulty to maintain dividend payments and they can share their profit with their shareholders. Although in the literature firms with more tangible assets are expected to pay more dividends, the tangibility of a firm, which proxies the asset structure of a firm, is negatively significant in the regressions which is consistent with the findings of Aivazian, Booth and Clearly (2003). Finally, the last control variable, foreign ownership, which is used to estimate the information asymmetry, has a negative influence on dividend payout policy. We predict a positive impact of foreign ownership on dividend payouts, in Turkey foreign ownership reduces the dividend payments. All in all, these findings support the view that large, profitable firms with low investment opportunities distribute more dividend to their shareholders than other firms do (in a country with weak investor protection).

\section{Conclusion}

With the surge up of the importance of corporate governance prevailing in the corporate world, it has become necessary to explore the relationship between possible external governance mechanisms and corporate decisions. Competition is an external corporate control mechanism which serves a monitoring function and reduces the agency problems (Allen \& Gale, 2000). The competition in the market puts pressure on management and influence corporate policies.

This study aims to analyze the effect of product market competition on corporate dividend payout policy. Competition mitigates agency conflicts and motivates managers to be more aligned with the shareholders. Thus, it is expected to have higher dividend payments in highly competitive industries. On the other hand, in a highly competitive market, firms need more free-cash flow to catch up investment opportunities and to remain competitive in the market. So, from this point of view, it is expected to have higher dividend payments in concentrated industries. In this study, we aim to explore the influence of competition on dividend payout policy of Turkish firms.

This study has been conducted for Turkish non-financial listed firms. The competition is estimated by two different measures commonly used in literature: $\mathrm{HHI}$ and 5-firm concentration ratio. The analyses with both competition measures show that the competition in the market negatively impacts the dividend payout of a firm. The findings indicate that in highly competitive industries, Turkish firms pay lower dividends than the firms in concentrated industries to remain competitive in the market. In Anglo-Saxon countries, with dispersed ownership and higher minority shareholder's rights like the U.S., the disciplinary force of competition makes managers distribute higher dividends to shareholders (Grullon \& Michaely, 2007). Contrary to the U.S., Turkey has a French civil law system which provides weak investor protection. In addition to being a civil law country, Turkish firms have concentrated ownership structure with powerful large shareholders. In such conditions, the disciplinary force of competition on management 
does not lead higher dividend payments like in the U.S. market. The priority of management in Turkey is to remain competitive in the industry. In a weak investor protection county like Turkey, the substitute agency model of dividends prevails.

In this paper, the effect of product market competition on dividend payout has been analyzed in only one county, Turkey, which is accepted as a French-civil-law country. This study should be expanded to include other French civil law countries to get a grasp of the full picture of countries with weak investor protection. Furthermore, to fully understand how the competition affects the corporate payout policy, share repurchases might also be utilized as well as dividend payouts in analyses for both common-law countries and French-civil-law countries, which constitutes a future research topic. 


\section{References}

Aivazian, V., Booth, L., \& Clearly, S. (2003). Do Emerging Market Firms Follow Different Policies from U.S. Firms? Journal of Financial Research, 26(3), 371-387. https://doi.org/10.1111/1475-6803.00064

Allen, F., \& Gale, D. (2000). Corporate Governance and Competition. Corporate Governance: Theoretical and Empirical Perspectives. Cambridge University Press. (pp. 23-94).

Ammann, M., Oesch, D., \& Schmid, M. M. (2011). Corporate Governance and Firm Value: International Evidence. Journal of Empirical Finance, 18(1), 36-55. https://doi.org/10.1016/j.jempfin.2010.10.003

Baker, H. K., Farrelly, G. E., \& Edelman, R. B. (1985). A Survey of Management Views on Dividend Policy. Financial Management, 14(3), 78-84. https://doi. org/10.2307/3665062

Banerjee, S., Gatchev, V., \& Spindt, P. (2002). To Pay or not to Pay? The Dividend Dilemma of the Liquid Firm. AB Freeman School of Business Working Paper, Los Angeles: Tulane University. Bebczuk, 1415-1431.

Byun, H. S., Lee, J. H., \& Park, K. S. (2012). How Does Product Market Competition Interact with Internal Corporate Governance?: Evidence from the Korean Economy: How Competition Interact with Governance? Asia-Pacific Journal of Financial Studies, 41(4), 377-423. https://doi.org/10.1111/j.20416156.2012.01077.x

Byun, H. S., Lee, J. H., \& Park, K. S. (2014). Corporate Governance, Product Market Competition, and Payout Policy. Seoul Journal of Business, 20(1), 1.

Deangelo, H., Deangelo, L., \& Stulz, R. (2006). Dividend Policy and the Earned/Contributed Capital Mix: A Test of the Life-Cycle Theory. Journal of Financial Economics, 81(2), 227-254. https://doi.org/10.1016/j. jfineco.2005.07.005

Denis, D., \& Osobov, I. (2008). Why Do Firms Pay Dividends? International Evidence on the Determinants of Dividend Policy. Journal of Financial Economics, 89(1), 62-82. https://doi.org/10.1016/j. jfineco.2007.06.006

Fama, E. F., \& French, K. R. (2001). Disappearing Dividends: Changing Firm Characteristics or Lower Propensity to Pay? Journal of Financial Economics, 60(1), 3-43. https://doi.org/10.1016/S0304-405X(01)00038-1

Fee, C. E., \& Hadlock, C. J. (2000). Management Turnover and Product Market Competition: Empirical Evidence from the U.S. Newspaper Industry. The
Journal of Business, 73(2), 205-243. https://doi. org $/ 10.1086 / 209640$

Giroud, X., \& Mueller, H. M. (2010). Does Corporate Governance Matter in Competitive Industries? Journal of Financial Economics, 95(3), 312-331. https://doi. org/10.1016/j.jfineco.2009.10.008

Giroud, X., \& Mueller, H. M. (2011). Corporate Governance, Product Market Competition, and Equity Prices. The Journal of Finance, 66(2), 563-600. https:// doi.org/10.1111/j.1540-6261.2010.01642.x

Grullon, G., \& Michaely, R. (2007). Corporate Payout Policy and Product Market Competition. SSRN Electronic Journal. https://doi.org/10.2139/ssrn.972221

Guadalupe, M., \& Perez-Gonzalez, F. (2010). Competition and Private Benefits of Control. SSRN Electronic Journal. https://doi.org/10.2139/ssrn.890814

Hair, J. F., Black, W. C., Babin, B. J., \& Anderson, R. E. (2010). Multivariate Data Analysis. Prentice-Hall, International, Inc. (pp. 155-234)

He, W. (2012). Agency Problems, Product Market Competition and Dividend Policies in Japan: Accounting and Finance. Accounting \& Finance, 52(3), 873-901. https://doi.org/10.1111/j.1467-629X.2011.00414.x

Higgins, R. C. (1972). The Corporate Dividend-Saving Decision. The Journal of Financial and Quantitative Analysis, 7(2), 1527. https://doi.org/10.2307/2329932

Jensen, M. C. (1986). Agency Costs of Free Cash Flow, Corporate Finance, and Takeovers. The American Economic Review, 76(2), 323-329. http://www.jstor. org/stable/1818789

Jensen, G. R., Solberg, D. P., \& Zorn, T. S. (1992). Simultaneous Determination of Insider Ownership, Debt, and Dividend Policies. The Journal of Financial and Quantitative Analysis, 27(2), 247. https://doi. org/10.2307/2331370

Jeon, J. Q., Lee, C., \& Moffett, C. M. (2011). Effects of Foreign Ownership on Payout Policy: Evidence from the Korean Market. Journal of Financial Markets, 14(2), 344-375. https://doi.org/10.1016/j. finmar.2010.08.001

Kao, L., \& Chen, A. (2013). How Product Market Competition Affects Dividend Payments in a Weak Investor Protection Economy: Evidence from Taiwan. $\mathrm{Pa}$ cific-Basin Finance Journal, 25, 21-39. https://doi. org/10.1016/j.pacfin.2013.08.004

Kim, E. H., \& Lu, Y. (2011). CEO Ownership, External Governance, and Risk-Taking. Journal of Financial Eco- 
nomics, 102(2), 272-292. https://doi.org/10.1016/j. jineco.2011.07.002

La Porta, R., Lopes-de-Silanes, F., Shleifer, A., Vishny, R.W. (2000). Agency Problems and Dividend Policies around the World. Journal of Finance 55(1). https:// doi.org/10.1111/0022-1082.00199

Lie, E. (2000). Excess Funds and Agency Problems: An Empirical Study of Incremental Cash Disbursements. Review of Financial Studies, 13(1), 219-248. https:// doi.org/10.1093/rfs/13.1.219

Lintner, J. (1956). Distribution of Incomes of Corporations among Dividends, Retained Earnings, and Taxes. The American Economic Review, 46(2), 97-113.
Raith, M. A. (2001). Competition, Risk and Managerial Incentives. SSRN Electronic Journal. https://doi. org/10.2139/ssrn.262648

Redding, L. S. (1997). Firm Size and Dividend Payouts. Journal of Financial Intermediation, 6(3), 224-248. https://doi.org/10.1006/jfin.1997.0221

Rozeff, M. S. (1982). Growth, Beta and Agency Costs as Determinants of Dividend Payout Ratios. Journal of Financial Research, 5(3), 249-259. https://doi. org/10.1111/j.1475-6803.1982.tb00299.x

Schmidt, K. M. (1997). Managerial Incentives and Product Market Competition. The Review of Economic Studies, 64(2), 191. https://doi.org/10.2307/2971709 